Canadian University Music Review

Revue de musique des universités canadiennes

\title{
Borrowings in J.S. Bach's Klavierübung III
}

\section{Gregory G. Butler}

Numéro 4, 1983

URI : https://id.erudit.org/iderudit/1013904ar

DOI : https://doi.org/10.7202/1013904ar

Aller au sommaire du numéro

\section{Éditeur(s)}

Canadian University Music Society / Société de musique des universités canadiennes

\section{ISSN}

0710-0353 (imprimé)

2291-2436 (numérique)

Découvrir la revue

\section{Citer cet article}

Butler, G. G. (1983). Borrowings in J.S. Bach's Klavierübung III. Canadian University Music Review / Revue de musique des universités canadiennes, (4), 204-217. https://doi.org/10.7202/1013904ar

(c) Canadian University Music Society / Société de musique des universités canadiennes, 1983
Ce document est protégé par la loi sur le droit d'auteur. L'utilisation des services d'Érudit (y compris la reproduction) est assujettie à sa politique d'utilisation que vous pouvez consulter en ligne.

https://apropos.erudit.org/fr/usagers/politique-dutilisation/ 


\title{
BORROWINGS IN J. S. BACH'S KLAVIERÜBUNG III
}

\author{
Gregory G. Butler
}

J. S. Bach was no exception when it came to the firmly established Baroque custom of borrowing musical ideas, both from compositions of other composers as well as from one's own. These borrowings are important, for not only do they give us some idea of the music with which Bach came into contact and the aspects of these compositions that attracted him, they are also often illuminating for what they reveal to us of his creative process. Bach's Dritter Teil der Klavierübung, published in 1739, has not received detailed examination thus far in the search for the composer's borrowings, but here, as in so many of his works, borrowings are clearly in evidence.

The term "borrowing" is not a particularly fortuitous one, and it is used here only because it is in common usage among musicologists to refer to a specific process. It would appear, however, to be a far too crude and exclusive term, most inadequate in describing what is, in reality, a subtle and multi-faceted process. As if to emphasize this point, the three cases of borrowing under consideration here are all quite different in nature and cover a wide range of technical procedures.

The North German composer Conrad Friedrich Hurlebusch (ca.1695-1765) was a renowned keyboard virtuoso, an accomplished composer of keyboard music, cantatas, and opera, as well as a theorist, with plaudits from such figures as Johann Mattheson (see 1740: 120-25) and Johann Gottfried Walther (see 1732: 321). Even before 1734, Bach may well have heard about Hurlebusch and have seen some of his compositions. In fact, Hurlebusch may have visited Bach on a trip he made in 1726, since his road from Bayreuth to Dresden and hence home lay through Leipzig. That he visited Bach some years later, almost certainly sometime in 1734 , is clear from the following 
account of this visit which appeared later in the Allgemeine deutsche Bibliothek (1788):

Just one example as proof of his [J. S. Bach's] modesty, an example of which I was a witness. Bach once received a visit from Hurlebusch, a harpsichordist and organist who at that time was very famous. The latter, upon request, sat down at the harpsichord and what did he play for Bach [but] a printed menuet with variations. Thereupon Bach played seriously according to his manner. The stranger, struck by Bach's courtesy and friendly reception, made a gift of his printed sonatas to Bach's sons so that they might, as he said, study from it, unaware that Bach's sons knew how to play quite other things. Bach chuckled to himself, but remained unassuming and friendly (quoted in Nicolai 1788: 303). ${ }^{1}$

This somewhat amusing anecdote is important for more than simply what it reveals to us of Bach's character. The composition that Hurlebusch played for Bach can only have been the Minuetta con Variazoni, the impressive tour de force of variation writing that opens Hurlebusch's printed collection, Compositioni Musicali per il Cembalo divise in due parti, ${ }^{2}$ and it must be this work to which the anonymous observer alludes when he refers to "printed sonatas," since Hurlebusch, so far as can be ascertained, had published no sonata collection up to this time. If, as is likely, C. P. E. Bach is the source of this anecdote, the Compositioni Musicali, for which the date of publication is usually given as circa 1735 , must in fact have been published by 1734 , since C. P. E. Bach left Leipzig in September of that year for Frankfurt an der Oder.

Whatever Bach may have thought of Hurlebusch and his keyboard collection (Forkel [1920: 108], in recounting the Hurlebusch-Bach encounter, refers to Hurlebusch as "conceited and arrogant" and to his playing as "indifferent"), he agreed, probably at the time of this visit, to act as the Leipzig distributor for Hurlebusch's collection, for we learn from an announcement in the edition of the Leipzig journal Der eingelauffene Nouvelle for 19 November 1735 that copies of his Compositioni Musicali "are to be had right here in Leipzig from Capellmeister Bach at the Thomasschule for 3 thalers 12 groschen" (quoted in Neumann \& Schulze 1969: 256-57). ${ }^{3}$ But what is more important for this study is Bach's borrowing from Hurlebusch's publication.

One of the five fugues in the Compositioni Musicali, Number 
IV of Part Two of the work, clearly was Bach's source for the principal subject and the first of the three sections of the Fuga à 5. con pedale. pro Organo pleno in E-flat major, BWV 552,2, which concludes the composer's Dritter Teil der Klavierübung.

As is clear from a comparison of the principal subjects of both works (see Ex. 1a), Bach immediately discarded the descending sequential eighth-note figuration that makes up the concluding half of Hurlebusch's subject since it detracted from the severe, ponderous nature of the imposing initial fragment and since this figuration, in contrast to the strict treatment of the initial fragment, is treated in a free and highly inconsistent manner throughout the course of Hurlebusch's working out:
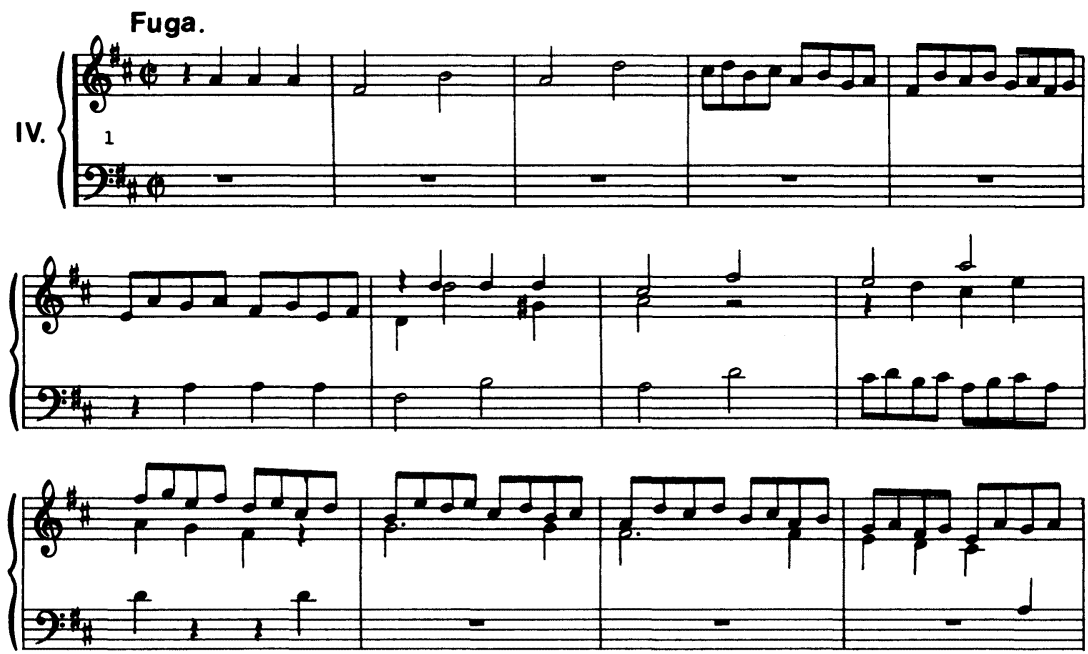

C.F. Hurlebusch: Compositioni musicali (1734?), Parte Seconda, IV. Fuga.

Fuga a 5 pro Organo pleno.

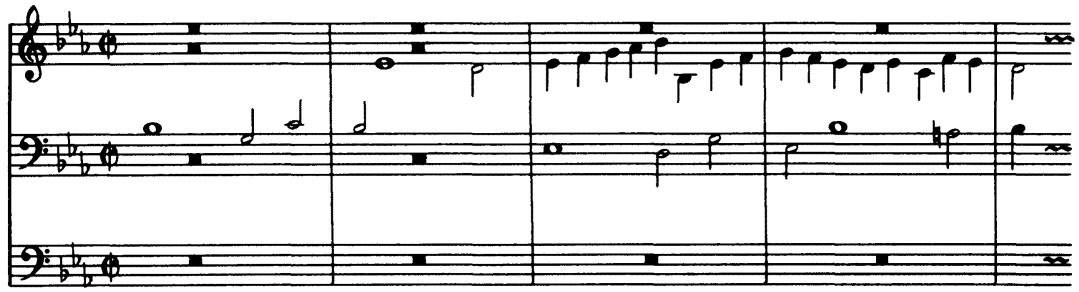

J.S. Bach: Dritter Teil der Klavierübung (1739), Fuga à 5

(BWV 552,2).

Example 1a 
Bach then adapted the opening rising sequential fragment of the Hurlebusch subject, transforming the initial pitch from a repeated note, upbeat figure into a single whole note. His second transformation of this initial fragment of the Hurlebusch subject consisted of doubling the concluding note of the fragment to produce a syncopated suspension figure which resolved to the leading tone in a concluding cadential construction. This second and most important transformation is not an original one. Bach must have been struck initially by the potential for treatment of this initial fragment in close stretto as realized by Hurlebusch in passages such as that reproduced in Example 1b. $\mathrm{He}$ thus combines elements of Hurlebusch's principal subject and his second countersubject to arrive at his stretto combination:

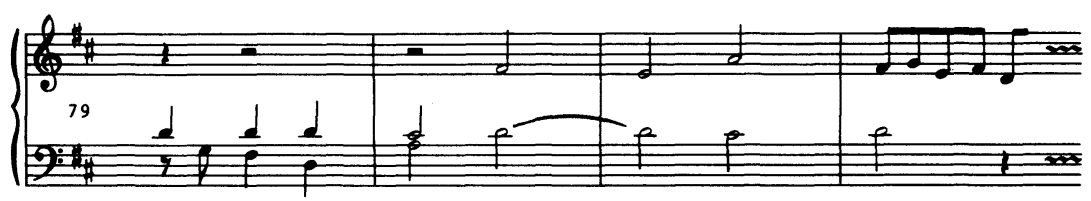

Hurlebusch

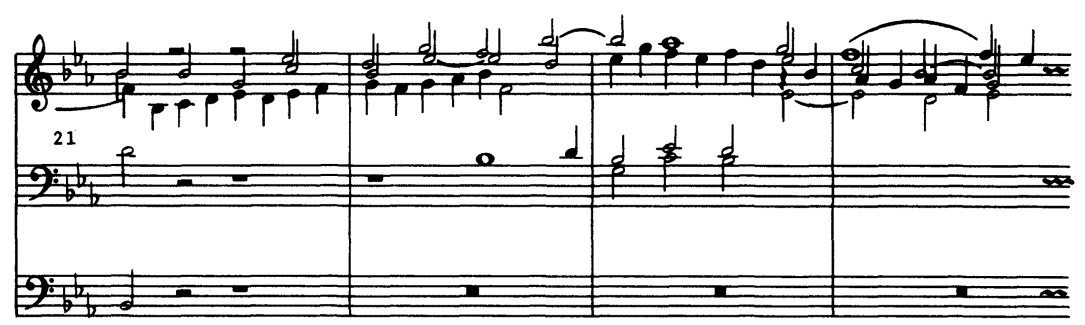

Bach

Example 1b

Hurlebusch's writing is notable, above all, for its striking rapid chromatic modulations, and Bach has borrowed one such passage verbatim from Hurlebusch's working out, taking it over in one of his stretto combinations in a slightly altered rhythmic form: 


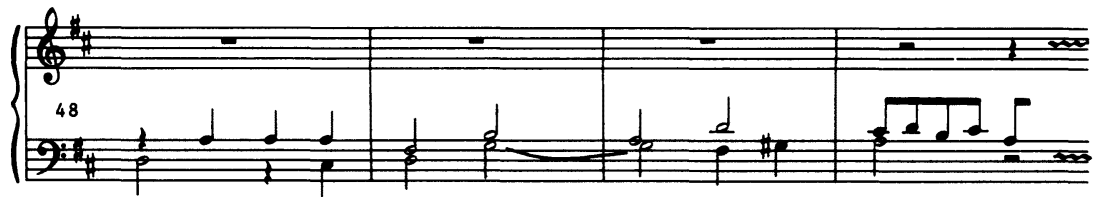

Hurlebusch

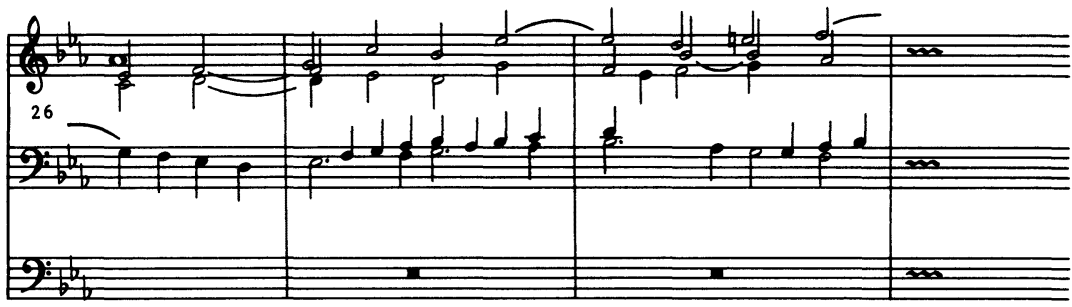

Bach

Example 1c

There is also some evidence that Bach's dominant sequential treatment in this portion of the fugue may have derived from that employed by Hurlebusch. It should be clear from the following example, however, that Bach's adaptation of this sequential structure is infinitely richer and more varied than Hurlebusch's treatment:

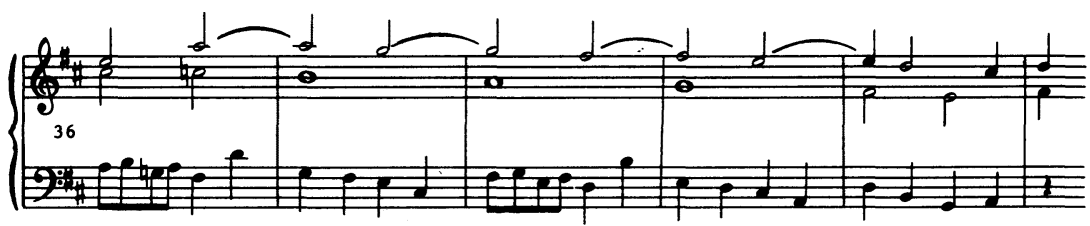

Hurlebusch

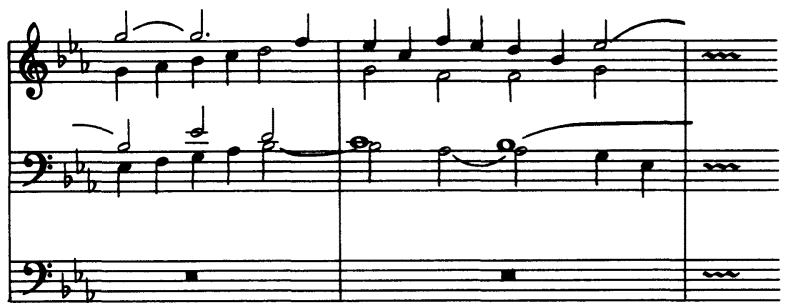

Bach

Example 1d 
Throughout, Bach disguises the mechanically repetitive nature of the sequence by restricting the frequency of sequential repetition to one statement per measure and by distributing the sequential units among the various voices to create a complex imitative web.

Commentators have suggested innumerable sources for the subject of this fugue: an original creation springing ready-formed from Bach's genius, a commonplace thematic fundament adopted by Bach from the public domain, or an adaptation of the cantus firmus of a chorale tune. More specifically, the opening subject of the fugue from Dietrich Buxtehude's Praeludium und Fuga in E major has often been suggested as a likely source for Bach's subject:

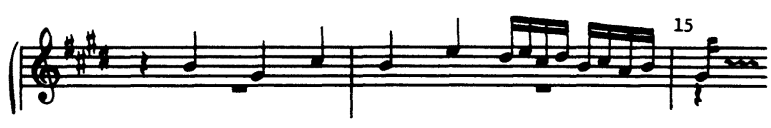

D. Buxtehude: Praeludium (BuxWV 141).

Example 1e

It is by no means certain, however, that Bach ever heard or saw in manuscript Buxtehude's work. Moreover, Buxtehude's subject consists entirely of quarter and eighth notes. What is interesting is that Hurlebusch's subject is very close to Buxtehude's, preserving almost note for note the descending sequential eighthnote figuration that concludes Buxtehude's subject. It would seem likely that the Buxtehude subject was Hurlebusch's source but not Bach's. What is important here is that Bach had in his possession the published source in which Hurlebusch's work appeared; furthermore he seems to have adopted certain compositional procedures directly from Hurlebusch's fugue. This sort of appropriation of musical material either literally or with some basic modification is fairly typical of the process commonly associated with the term "borrowing," and numerous similar examples can be found throughout Bach's oeuvre.

Bach's cousin, Johann Gottfried Walther (1684-1748), the famed German organist, composer, theorist, and lexicographer, had been town organist at Weimar for a year when Bach joined the ducal court orchestra there in 1708. Walther's numerous chorale settings are of a uniformly high quality and are perhaps the only significant collection of pieces in this genre comparable to the chorale settings of Bach. There is evidence of a strong 
mutual influence in the chorale settings of both composers and it would appear that this influence, along with the close personal friendship established between Walther and Bach, was not limited to Bach's Weimar years, but extended well into the Leipzig period. On 26 January 1736 Walther wrote a letter to Heinrich Bokemeyer; speaking of his attempt to have his eight variations on the chorale Allein Gott in der Höh' sei Ehr' published, Walther writes that "they have been shown and recommended to Herr Krügner in Leipzig by Herr Capellmeister Bach" (quoted in ibid.: 265).${ }^{4}$ From this letter it is certain that Bach had received and examined a manuscript copy of Walther's chorale variations, probably sometime toward the end of 1735 , and that he had recommended them to the Leipzig engraver and printer Johann Krügner, who, after examining them himself, had rejected them.

A comparison of Walther's eight settings with the three settings of the same chorale in Bach's Dritter Teil der Klavierübung reveals a close relationship between Walther's Vers $V$ and the second of Bach's settings for two manuals and pedal (BWV 676). In this case, the borrowing is not a thematic one since both compositions are based on the same chorale melody. The similarity lies in the treatment of the cantus firmus by the two composers. Example 2 compares the treatment of the first six phrases of the cantus firmus in the respective settings. Both works are in the key of $\mathrm{G}$ major and both are in triple time. Whereas Walther states the cantus firmus in alternating short and long values Bach states it essentially in equal note values. The accompanying contrapuntal elaboration, needless to say, is entirely different in each case; however, the layout and overall treatment of the cantus firmus is similar.

Walther's treatment is unique to begin with. In his repetition of the first two phrases of the chorale melody, he inverts all the parts at the octave with the result that the cantus firmus migrates from the soprano to the bass voice. The next two phrases are stated in canon at the lower fifteenth with the comes in the bass following the dux in the soprano at the distance of one measure. Bach states the first two phrases of the chorale melody at the same pitch as Walther but in the middle voice. In the repetition of these two phrases, Bach also employs invertible counterpoint at the octave. It is not triple counterpoint as in the Walther setting but involves only the upper two voices. Bach's setting of the next two phrases of the 

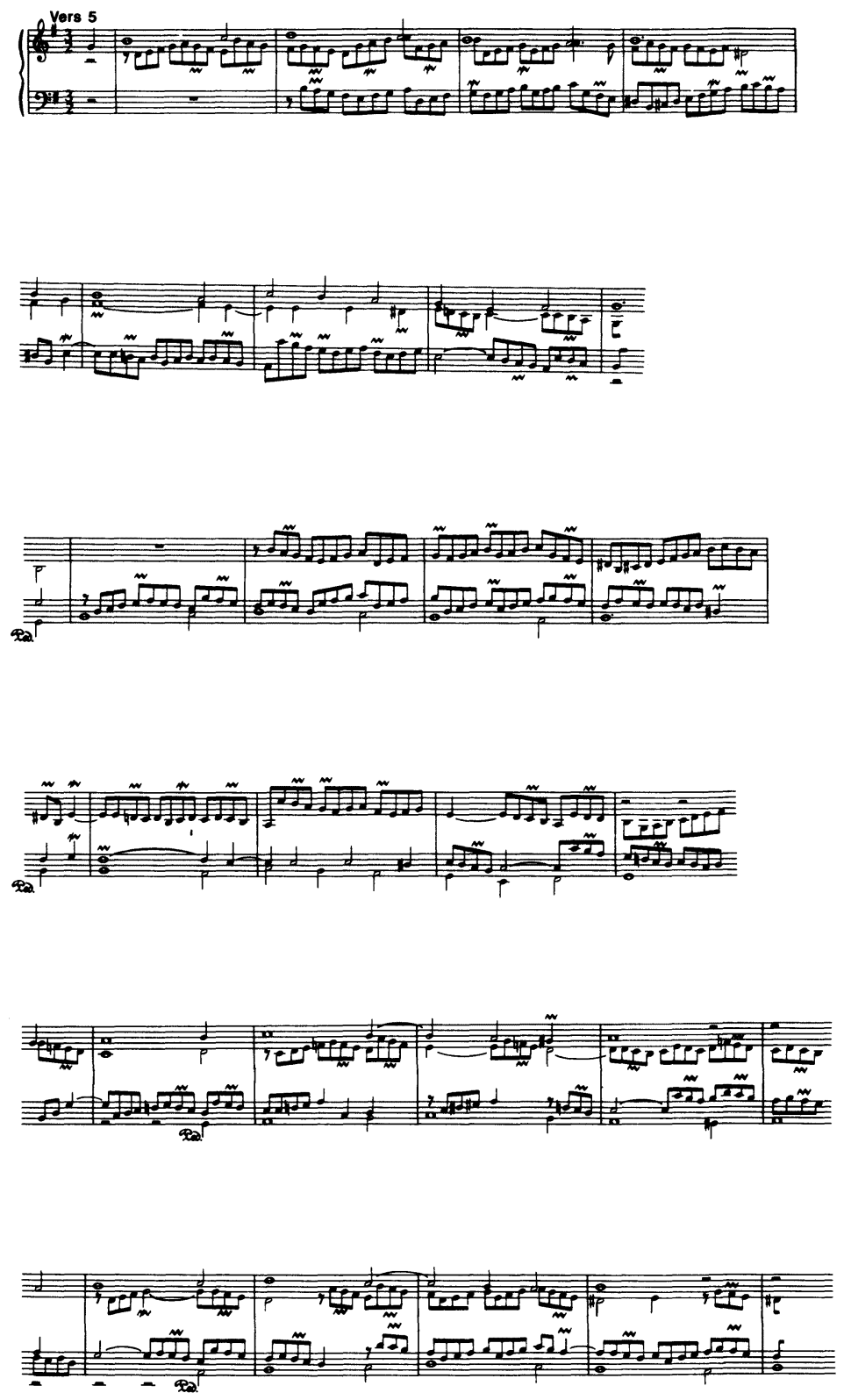

J.G. Walther: Acht Vorspielen über das Lied: Gott in der Höh sei Ehr' (1738), Vers 5. 

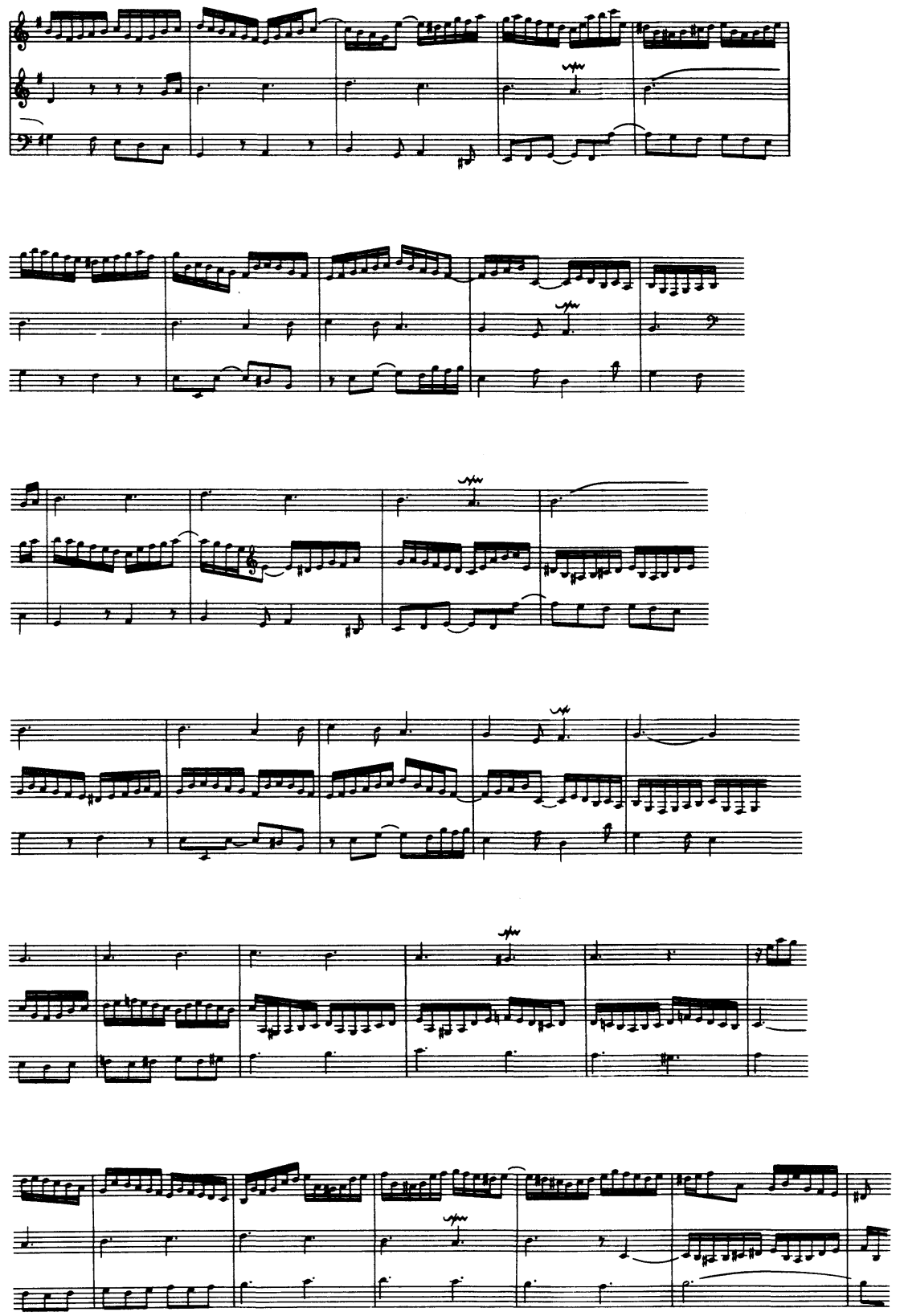

J.S. Bach: Dritter Teil der Klavierübung (1739), Allein Gott in der Höh sei Ehr' (BWV 676).

$$
\text { Example } 2 \text { (continued) }
$$


cantus firmus is identical to Walther's. The only striking difference between the two treatments occurs in the final phrase, which is not shown in Example 2. Instead of simply continuing in canon, as Walther does, Bach treats this last phrase with startling originality. He first states the phrase fugally in two articulated voice pairings. The first pair enter in alto and soprano in the tonic and dominant, respectively, the last pair in stretto in the bass and soprano, both in the tonic.

This is at the farthest remove from the first instance of borrowing discussed above in that it is the least literal and most abstract type. As such it is clearly the most difficult type to substantiate. However, in this case the claim can be justified mainly on the basis of the similarity in approach to the treatment of the cantus firmus. It is unusual for Bach to subject a cantus firmus to more than a single compositional device in the same setting, but to employ three different techniques, as in this setting, is most unusual. Also, the use of invertible counterpoint for the repeat in the Stollen is rather unusual. It would appear that it was the treatment of the cantus firmus in Walther's variation that acted as a stimulus for Bach and provided the model which he elaborated upon and in fact surpassed in his conception.

In most studies tracing Bach's borrowings, researchers seem to have taken the position that simply establishing parallels between certain compositions of other composers and those of Bach is sufficient evidence that borrowing has indeed taken place, even though there may be no proof whatsoever that Bach ever came in contact with the source in question. For the most part such contact is highly doubtful, since the majority of the works in question were not published at the time but preserved in manuscript only. Both instances of borrowing outlined above, however, come from contemporary printed sources and in both cases there is documentary proof that Bach possessed copies of the two prints.

Obviously any newly substantiated Bach borrowings must be of great interest to Bach scholars. But the first two examples of borrowing under consideration here are of particular significance, for they have important implications for the proper dating of the Klavierübung III. It has been generally assumed that Bach wrote virtually all the settings in this collection just prior to the printing of the work in 1739 (see Tessmer 1974: 31). It is clear, however, that Bach had seen both the sources of his 
borrowing before the end of 1735 . It would seem quite possible, therefore, that the composition of at least these two parts of the Klavierübung III might date from as early as $1734-35$ for the Fuga à 5 and as early as 1736 for the setting of Allein Gott in der Höh' sei Ehr'. As a final point it might also be suggested that Walther's variations on the Gloria of the Missa may have influenced Bach in his decision to include the Missa settings in his collection.

The third and final borrowing to be discussed here, a selfborrowing, is not so much a borrowing as a reworking of a fugal fundament found in an earlier organ fugue of Bach's own composition. Example 3 offers a comparison of the opening measures of the Fuga from Bach's, Praeludium et Fuga in C, BWV 545, with the opening of the initial fugal section of the Praeludium pro Organo pleno, BWV 552,1:

a)
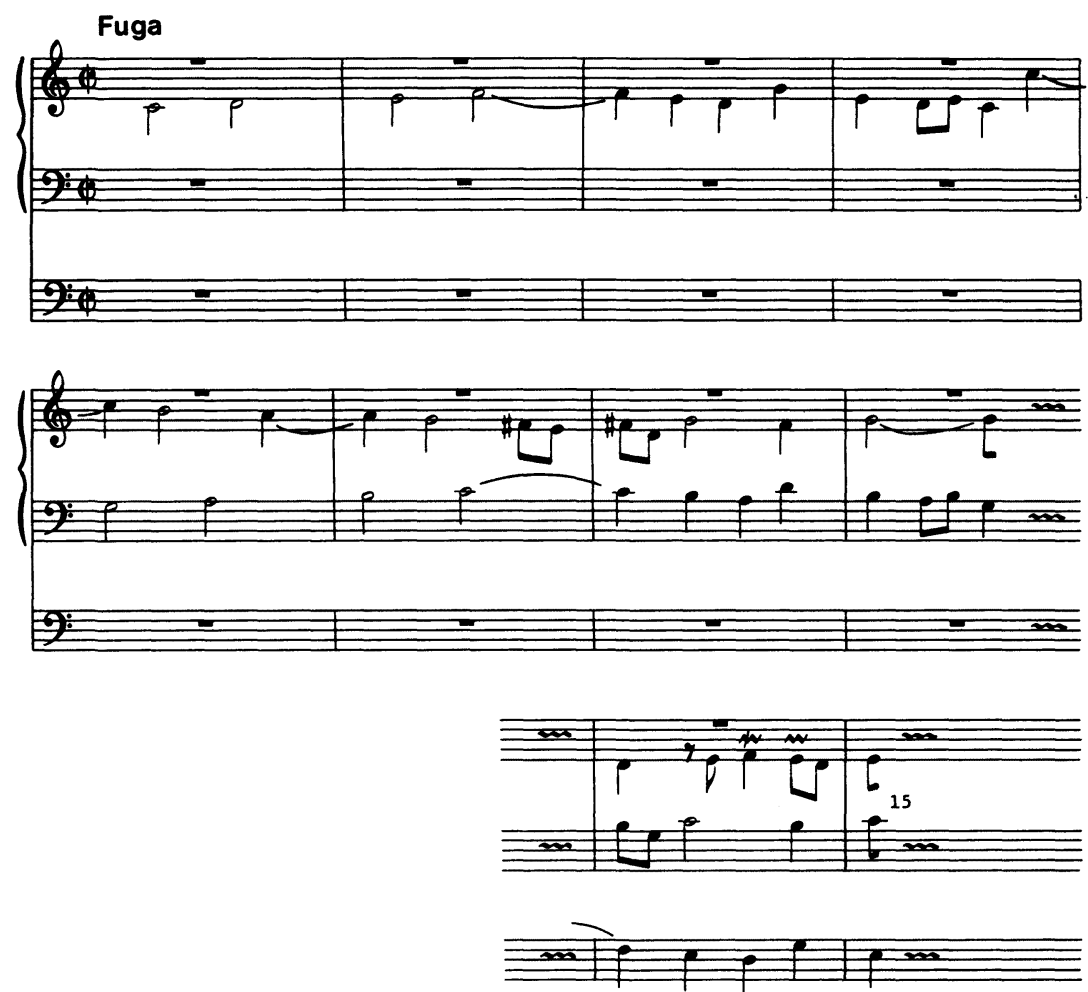

J.S. Bach: Praeludium et Fuga in C (1708-17) (BWV 545). 
b)

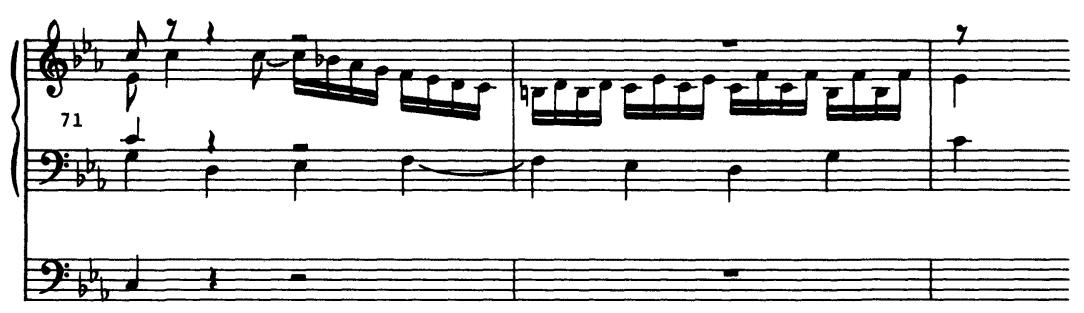

J.S. Bach: Dritter Teil der Klavierübung (1739), Praeludium pro Organo pleno (BWV 552,1).

Example 3

The subject of the earlier fugue is identical melodically with the countersubject in the later work. The only difference between the two is diminution by half in the value of the first four notes in the later reworking. This difference is reflected in the extension in the later work of the descending passage that opens the countersubject in the earlier one; but the closing portions in both cases are almost identical. Included in Example 3 is the harmonic elaboration provided by the third free voice with the pedal entry in measure 14 of the earlier fugue. This third free voice is already present in the broken sixteenth-note figuration of the subject in the later work. It is clear from the exchange of fugal functions of subject and countersubject and the overall freedom of the reworking here that we are dealing with anything but a literal borrowing. The invariable element here, the countrapuntal fundament, is below the surface while the surface is variable by way of the diminution employed in each case. ${ }^{5}$

These three examples of borrowing in Bach's Klavierübung III document the general nature of borrowing as a compositional process and concomitantly reveal certain problems with the term itself as it appears in established usage. Bach's borrowings in the Klavierübung III as elsewhere, sublime transformations that they are, splendidly adhere to Johann Mattheson's stricture concerning the whole matter of borrowing:

Borrowing is a permissible thing, but one must return the loan with interest. That is, one must arrange and work out imitations in such a way that they acquire a more beautiful and superior aspect than the pieces from which they are borrowed (1739: 131). ${ }^{6}$ 


\section{NOTES}

1. "Nur ein Beispiel zum Beweise seiner Bescheidenheit, wovon ich Zeuge gewesen bin. Bach kriegte einsmals einen Besuch von Hurlebusch, einen Klavier- und Orgelspieler, welcher damals sehr berühmt war. Dieser letztere setzte sich auf Ersuchen an den Flügel; und was spielte er Bachen vor? Eine gedruckte Menuet mit veränderungen. Hierauf spielte Bach ganz ernsthaft nach seiner Art. Der Fremde von Bachs Höflichkeit und freundlicher Aufnahme durchdrungen, machte Bachs Kindern mit seinen gedruckten Sonaten ein Geschenk damit sie daraus, wie er sagte, studieren sollten, ohngeachtet Bachs Söhne schon damals ganz andere Sachen zu spielen wussten. Bach lächelte für sich, blieb bescheiden und freundlich."

2. Modern edition edited by Max Seiffert (Amsterdam - Leipzig: G. Alsbach and Breitkopf \& Härtel, 1912).

3. "Bei Herrn Capellmeister Bachen allhier sind für 3. und einen halben Thlr...."

4. "Herrn Krügnern in Leipzig sind sie vom Herrn Capellm. Bachen gezeiget v. recommendiret worden."

5. There are other examples of this sort of recycling of fugal fundaments elsewhere in Bach's works. One striking example is the reuse of the fugal fundament from Fuga 17 in A-flat major from Das wohltemperierte Klavier II in the concluding portion of the Ricercar à 6 in Das musicalische Opfer.

6. "Entlehnen ist eine erlaubte Sache; man muss aber das Entlehnte mit Zinsen erstatten, d. i. man muss die Nachahmungen so einrichten und ausarbeiten, dass sie ein schöneres und besseres Ansehen gewinnen, als die Sätze, aus welchen sie entlehnet sind." 


\section{REFERENCES}

FORKEL, J. N.

1920: Johann Sebastian Bach: His Life, Art and Work (1802). Translated by Charles Sanford Terry. London: Constable.

MATTHESON, J.

1739: Der vollkommene Kapellmeister. Hamburg: C. Herold.

1740: Grundlage einer Ehrenpforte. Hamburg: J. Mattheson.

NEUMANN, W. and SCHULZE, H-J., eds.

1969: Bach Dokumente, herausgegeben vom Bach-Archiv Leipzig, Supplement zu Johann Sebastian Bach Neue Ausgabe sämtlicher Werke. Band II: Fremdschriftliche und gedruckte Dokumente zur Lebensgeschichte Johann Sebastian Bachs 1685-1750. Kassel: Bärenreiter-Verlag.

NICOLAI, F., ed.

1788: Allgemeine deutsche Bibliothek. Des ein und achtzigsten Bandes erstes Stück. Berlin - Stettin: F. Nicolai.

TESSMER, M.

1974: Kritischer Bericht (1974) to Johann Sebastian Bach. Neue Ausgabe sämtlicher Werke (NBA), IV/4. Kassel: BärenreiterVerlag.

WALTHER, J. G.

1732: Musikalisches Lexikon. Leipzig: W. Deer. 